\title{
Mind the Valve: Ventricular Tachycardia Ablation Post-Valve Interventions
}

\author{
Matthew Hanson ${ }^{1}$ and Andres Enriquez ${ }^{2}$ \\ ${ }^{1}$ Queen's University \\ ${ }^{2}$ Kingston General Hospital
}

January 24, 2022

Hosted file

Editorial VT and valve interventions 4.doc available at https://authorea.com/users/457043/ articles/553915-mind-the-valve-ventricular-tachycardia-ablation-post-valve-interventions 